\title{
Development of effective heparin extraction method from pig by-products and analysis of their bioavailability
}

\author{
Da Young Lee ${ }^{1}$, Seung Yun Lee ${ }^{1}$, Hea Jin Kang ${ }^{1}$, Yeonhwa Park ${ }^{2}$ \\ and Sun Jin Hur ${ }^{1 *}$ \\ ${ }^{1}$ Department of Animal Science and Technology, Chung-Ang University, Anseong 17546, Korea \\ ${ }^{2}$ Department of Food Science, University of Massachusetts Amherst, Amherst, MA 01003, USA
}

Received: Aug 28, 2020

Revised: Sept 15, 2020

Accepted: Sept 15, 2020

*Corresponding author

Sun Jin Hur

Department of Animal Science and Technology, Chung-Ang University, Anseong 17546, Korea.

Tel: +82-31-670-4673

E-mail: hurs@@cau.ac.kr

Copyright ( 2020 Korean Society of Animal Sciences and Technology.

This is an Open Access article distributed under the terms of the Creative Commons Attribution Non-Commercial License (http:// creativecommons.org/licenses/by$\mathrm{nc} / 4.0 /$ ) which permits unrestricted non-commercial use, distribution, and reproduction in any medium, provided the original work is properly cited.

ORCID

Da Young Lee

https://orcid.org/0000-0002-3172-0815

Seung Yun Lee

https://orcid.org/0000-0002-8861-6517

Hea Jin Kang

https://orcid.org/0000-0001-6765-3434

Yeonhwa Park

https://orcid.org/0000-0001-9727-0899

Sun Jin Hur

https://orcid.org/0000-0001-9386-5852

Competing interests

No potential conflict of interest relevant to this article was reported.

Funding sources

This work was supported by Korea Institute of Planning and Evaluation for

\section{Abstract}

This study was conducted to develop an effective heparin extraction method by using lowcost and highly effective enzymes from six pig by-products (liver, lung, heart, stomach, small intestine, and large intestine), and analyze their bioavailability. Low-cost and highly effective enzymes (alkaline-AK and papain) and a common enzyme (trypsin) were used for the heparin extraction. The angiotensin I - converting enzyme (ACE) inhibitory activity and the antimicrobial activity of extracted heparin were analyzed to verify their bioavailability. The average amount of heparin extracted per kilogram of pig by-products was $439 \mathrm{mg}$ from the liver, 127 $\mathrm{mg}$ from the lung, $398 \mathrm{mg}$ from the heart, $261 \mathrm{mg}$ from the stomach, $197 \mathrm{mg}$ from the small intestine, and $239 \mathrm{mg}$ from the large intestine. Various enzymes were used to extract heparin, and the amount of extracted heparin was similar. Based on $1 \mathrm{~g}$ of pig by-product, the enzymes trypsin, papain, and alkaline-AK could extract 1,718 mg, 1,697 mg, and 1,905 mg of heparin, respectively. Heparin extracted from pig by-products showed antihypertensive activity and antimicrobial activity against Staphylococcus aureus at low populations. These results indicated that heparin can be obtained from pig by-products at a low cost.

Keywords: Alkaline-AK, Angiotensin I -converting enzyme (ACE) inhibitory activity, Antimicrobial activity, Heparin extraction, Pig by-products

\section{INTRODUCTION}

Despite increasing meat consumption, the use of slaughter by-products is limited owing to the increase in the volume of imported by-products, the lack of improvement in consumer awareness, and a lack of product development [1,2]. The efficient use of by-products from the meat production process is very important not only in reducing waste, but also in improving the efficiency of utilization of livestock products. Although the utilization rate is not high owing to a low efficiency of extraction, there are many bioactive substances in meat by-products, such as heparin, collagen, chenodeoxycholic acid (CDCA), and ursodeoxycholic acid (UDCA), conjugated linoleic acid (CLA) [3-5].

Among the many bioactive substances in meat by-products, heparin is a compound carbohydrate 
Technology in Food, Agriculture, Forestry and Fisheries (IPET) through High Valueadded Food Technology Development Program funded by Ministry of Agriculture, Food and Rural Affairs (MAFRA) (11803903-3-WT031). This research was supported by the Chung-Ang University Graduate Research Scholarship in 2019.

Acknowledgements Not applicable.

Availability of data and material Upon reasonable request, the datasets of this study can be available from the corresponding author.

Authors' contributions

Conceptualization: Hur SJ.

Methodology: Lee DY, Lee SY, Kang HJ. Investigation: Lee DY.

Writing - original draft: Lee DY.

Writing - review \& editing: Park Y, Hur SJ.

Ethics approval and consent to participate This article does not require IRB/IACUC approval because there are no human and live animal participants. that is an anticoagulant (blood thinner) to prevent blood clotting [6]. It is a polysaccharide of glycosaminoglycans with a strong negative charge and is found on the cell surface and in the extracellular matrix [6]. It was also confirmed in the 1950s that the activity of anti-thrombin was accelerated by heparin $[7,8]$. Heparin is widely distributed in various tissues such as the lung, liver, blood, and intestinal tissues of higher animals, especially in the mast cells. Heparin, which is used in laboratories and clinics, is generally extracted from the bovine heart or the small intestinal mucosa of swine, and is made into a calcium or sodium salt through enzymatic and chemical treatment [6].

Heparin is especially used for preventing of blood clotting during ventrotomy and organ transplantation, deep vein thrombosis, or heart thrombosis that develops as a result of blood circulatory deterioration. In addition, it has many biological functions, such as anti-inflammatory, antithrombotic, antihyperlipidemic, and anti-arteriosclerotic properties, as well as anticoagulant function that inhibits thrombin activity $[9,10]$. Previous studies have shown that heparin inhibits the production of angiotensin by renin and inhibits aldosterone secretion, and ultimately has an antihypertensive effect [11-13]. Infection and thrombosis are the most common complications of central venous catheters. Various gram-positive and negative bacteria cause catheter-related sepsis through central venous catheter $[14,15]$. The antibacterial activity of heparin was confirmed in various bacteria related to the above [14-18].

However, it is very expensive and time consuming to extract and purify heparin from pork by-products. Moreover, there are no studies comparing the amount of heparin in each pig by-product. Therefore, the purpose of this study was to develop a low- cost and highly efficient heparin extraction method in seven major pig by-products and analyze the anti-angiotensin I-converting enzyme (ACE) inhibitory activity in the extracted heparin and the antimicrobial activity against pathogenic microorganisms.

\section{MATERIALS AND METHODS}

\section{Pre-processing of pig by-products}

Six pig by-products (liver, lungs, heart, stomach, small intestine, and large intestine) for the extraction of heparin were obtained from the Dodram slaughter house (Anseong, Korea) and Woo-gyeung Livestock (Hwaseong, Korea). The pig by-products were transported to the laboratory and cleaned with tap water and then the bronchi connection to the lungs and esophageal connection to the stomach were severed, and the non-discharged digest inside and outside the organs was washed. After washing, the by-products were ground using a chopper, then subdivided, and stored frozen (Fig. 1).

\section{Heparin extraction in pig by-products}

Methods for the extraction of heparin from pig by-products were described previously by Charles and Scott [19-21], Freeman et al. [22], Volpi [23], and Sarwar [24] with modifications in order to simplify the extraction. Folch I solution (chloroform-methanol mixture, 2:1 by volume) was added to the by-product samples and homogenized using a homogenizer (SHG-15D-Set, SciLab-brand, Seoul, Korea) for autolysis. After shaking every $30 \mathrm{~min}$ for $3 \mathrm{~h}$, the crude fat was extracted and the solution and by-product tissues were separated. The Folch I solution used in the extraction of crude fat was separated by adding $0.88 \% \mathrm{NaCl}$ solution and left overnight. The chloroform layer (the lower layer) in which fat was precipitated was dried to obtain crude fat. The by-product tissue was rinsed once with $250 \mathrm{~mL}$ of acetone, completely dried at low temperature, and stored frozen. Crude fat and protein obtained in the process of extracting heparin can be used to extract other high-value-added materials present in pig by-products (Fig. 2). 


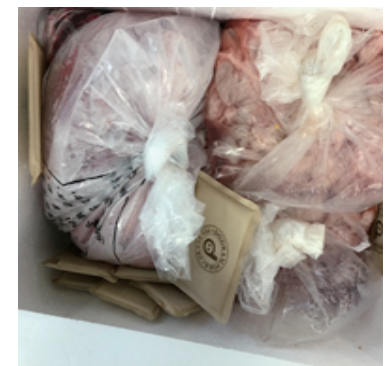

The pigs by-products slaughter on the morning of the day are received at low temperatures.

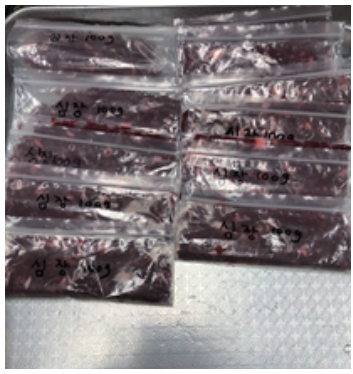

Subdivided pig by-products are stored frozen at $-4^{\circ} \mathrm{C}$.

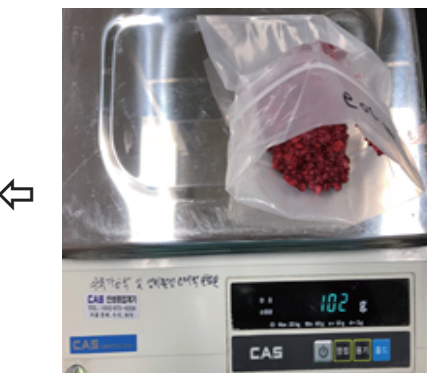

The pulverized organs are subdivided into appropriate

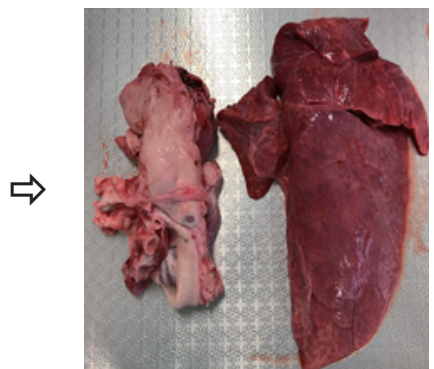

Before washing, bronchi connected with the lungs and the esophagus connected to the lung are removed. amounts.

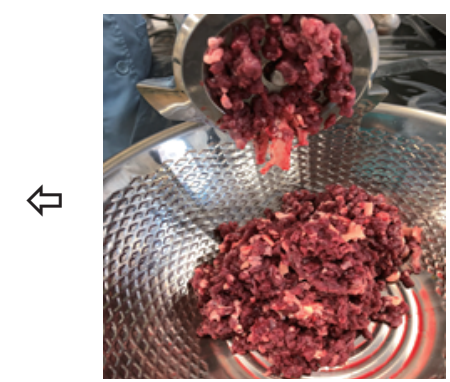

The washed organs are crushed using a chopper.
$\Rightarrow$

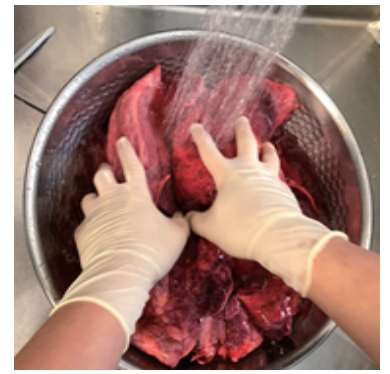

The liver, lungs, and heart are cleaned of impurities on the surface.

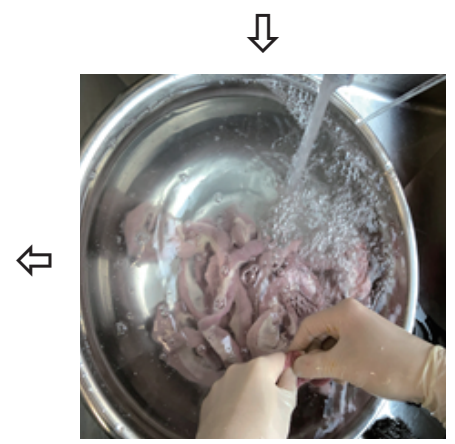

The stomach, small intestine, large intestine, not only the surface but also the inside of the organ is flipped over.

Fig. 1. Preparation of pig by-products.

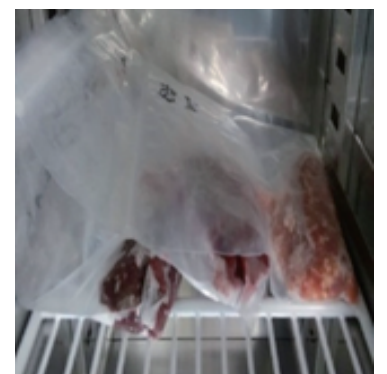

$500 \mathrm{~g}$ of organ by-products is chopped and autolyzed at $25^{\circ} \mathrm{C}$ for $24 \mathrm{~h}$.

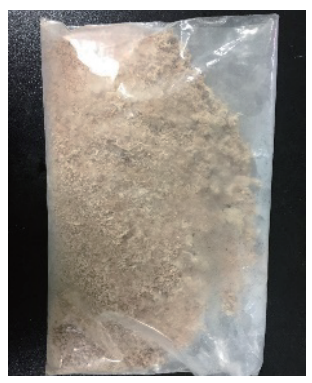

Crush and keep frozen.

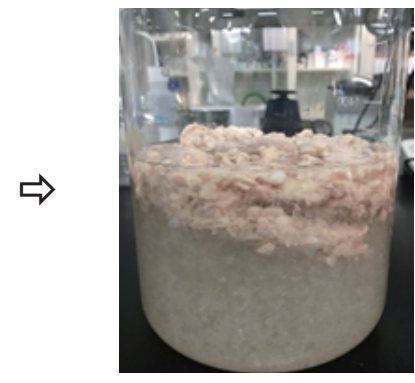

Add the five times Folch I solution as much as organ by-products.

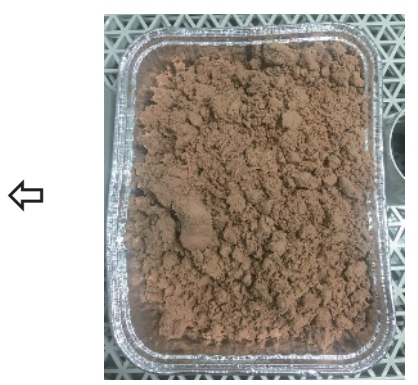

Dry in a cool place.

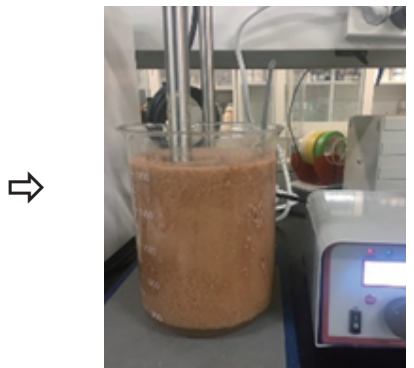

Mix thoroughly using homogenizer.

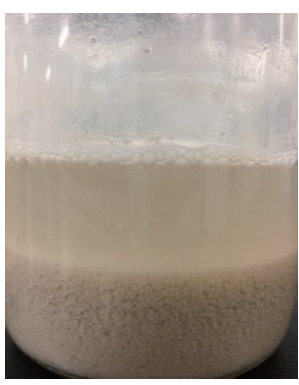

Add $250 \mathrm{~mL}$ of acetone to the grounds to thoroughly rinse the fat.

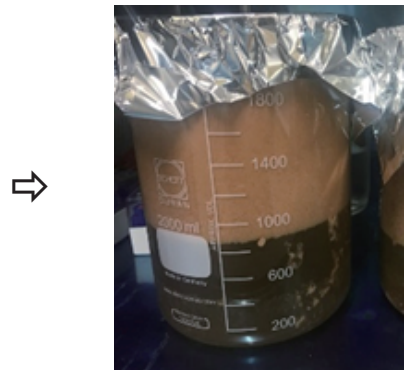

Allow to stand in the refrigerator for $3 \mathrm{~h}$, and mix occasionally.

』

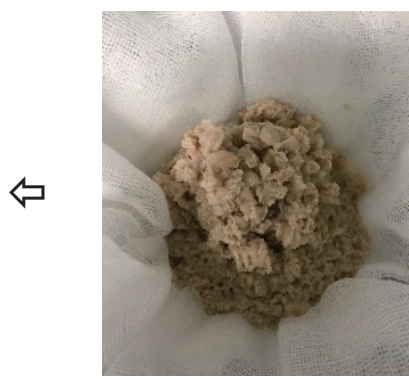

Use a gauze to separate the grounds. The liquid can extract crude fat with $0.85 \% \mathrm{NaCl}$.

Fig. 2. Procedures of defatting/dehydration treatment of pig by-products. 
The method for extracting heparin from dried by-products after degreasing proceeded on the basis of the amount of dry by-product powder. To $100 \mathrm{~g}$ of dried by-products, $1,460 \mathrm{~mL}$ of $0.5 \mathrm{~N}$ $\mathrm{NaOH}$ and $174 \mathrm{~mL}$ of saturated ammonium sulfate solution were added and the mixture was extracted in a water bath at $60^{\circ} \mathrm{C}$ for $30 \mathrm{~min}$. Using gauze, discard the solids and collect the solution. Then, $7 \mathrm{~N}$ sulfuric acid was added to the solution for titration to obtain a $\mathrm{pH}$ of 2, which formed a precipitate. This solution was centrifuged (Combi 514R, Hanil Scientific, gimpo, Korea) at 2,691 × g for raw min to remove the precipitate. The supernatant was extracted with $200 \mathrm{~mL}$ of $95 \%$ ethyl alcohol at $25^{\circ} \mathrm{C}$ for $20 \mathrm{~h}$. The solution was centrifuged at $2,697 \times \mathrm{g}$ for $20 \mathrm{~min}$ to remove the supernatant, and $150 \mathrm{~mL}$ of alkaline water ( $\mathrm{pH} 10)$ was added to the precipitate. For each experiment, $0.5 \%$ of alkaline-AK was added to the by-product amount in the above mixture, and trypsin and papain were added at $0.25 \%$ of the by-product amount. After addition of $300 \mu \mathrm{L}$ xylene, the mixture was left at $60^{\circ} \mathrm{C}$ in a water bath $\left(37^{\circ} \mathrm{C}\right.$ for trypsin) for $12 \mathrm{~h}$. One hundred milliliters of $95 \%$ ethyl alcohol was added to the solution that had undergone proteolysis, and this was left for $20 \mathrm{~h}$. The resulting precipitate was collected by centrifuging at $2.691 \times \mathrm{g}$ for $30 \mathrm{~min}$, and dissolved in $50 \mathrm{~mL}$ of alkaline water ( $\mathrm{pH} \mathrm{10).} \mathrm{After} \mathrm{addition} \mathrm{of} 25 \mathrm{~mL}$ of acetone, the mixture was stirred sufficiently, and the supernatant was removed by centrifugation at $2.691 \times \mathrm{g}$ for $30 \mathrm{~min}$. Then, $25 \mathrm{~mL}$ of $95 \%$ ethyl alcohol was added to the precipitate and incorporated thoroughly by stirring, and the precipitate was dried to obtain the heparin (Fig. 3).

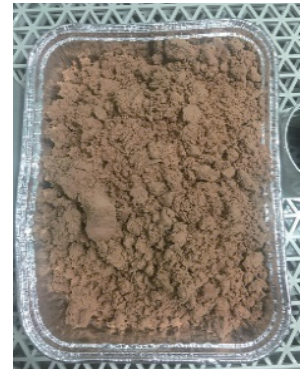

Add $1,460 \mathrm{~mL}$ of $0.5 \mathrm{~N}$ $\mathrm{NaOH}, 174 \mathrm{~mL}$ saturated ammonium sulfate and boil at $60^{\circ} \mathrm{C}$ for $3 \mathrm{~min}$.

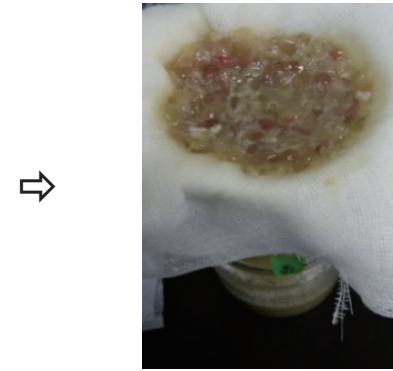

Samples are filtered through gauze.

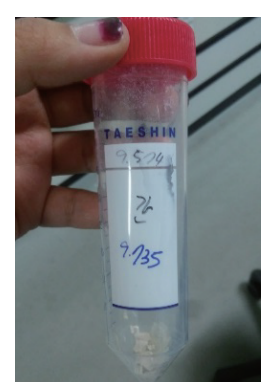

Collect the bottom layer by centrifugation, wash the precipitate by centrifugation with 25 $\mathrm{mL}$ of $95 \%$ ethanol.

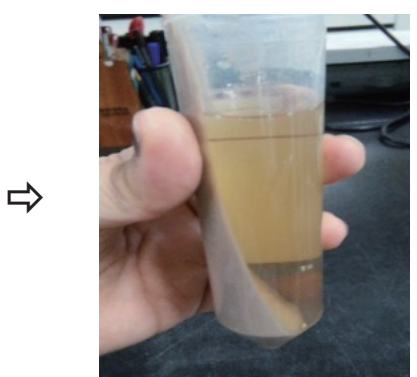

Add $7 \mathrm{~N}$ sulfuric acid to make a small amount of ammonium sulfate and remove it by centrifuge.

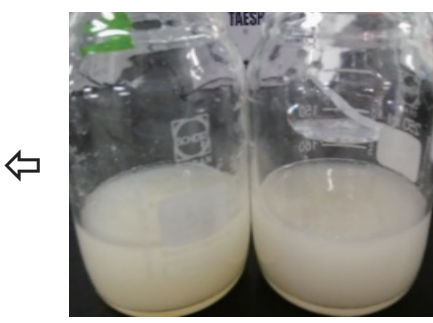

Add $100 \mathrm{~mL}$ of $95 \%$ ethanol, 20 $\mathrm{mL} 0.01 \mathrm{M} \mathrm{HCl}$ to solution and leave at room temperature for $20 \mathrm{~h}$. Centrifuged bottom layer is mixed with $50 \mathrm{~mL}$ of alkaline water with $25 \mathrm{~mL}$ of acetone.

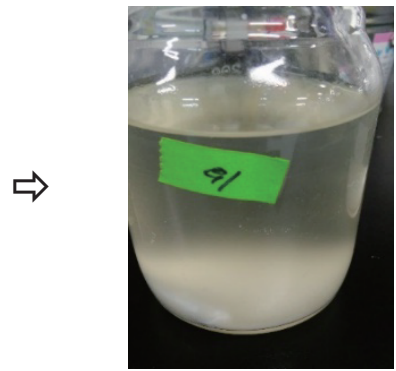

Add $200 \mathrm{~mL}$ of $95 \%$ ethanol to the top layer and leave at room temperature for $20 \mathrm{~h}$.

Л

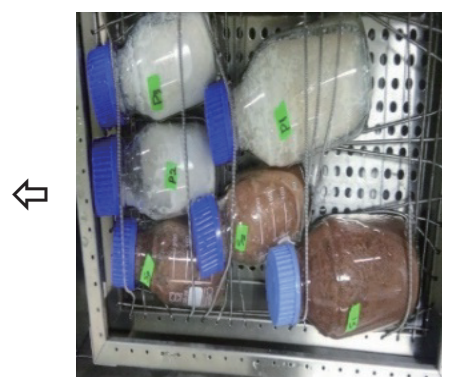

The bottom layer collected by centrifugation is dissolved in 150 $\mathrm{mL}$ of alkaline water $(\mathrm{pH} 10)$ and react by adding enzyme. 


\section{Quantification of heparin by high-performance liquid chromatography (HPLC)}

Heparin sodium salt from the porcine intestinal mucosa (192 USP unit/mg, Sigma-Aldrich, St. Louis, MO, USA) was used as a heparin standard reagent for HPLC analysis. Quantification of extracted heparin from pig by-products was performed according to the method of Arumugam and Shanmugam [25], with slight modifications. Standard solutions were prepared by dissolving the standard heparin in distilled water (DW) at concentrations of $0.625-10 \mathrm{mg} / \mathrm{mL}$. For the extracted heparin, HPLC analysis was carried out at a concentration of $2 \mathrm{mg} / \mathrm{mL}$ (Table 1).

\section{COATEST heparin assay}

Heparin sodium salt from porcine intestinal mucosa (192 USP unit/mg, Sigma-Aldrich) was used as a standard heparin reagent for heparin unit analysis and was analyzed using COATEST Heparin (Chromogenix, West Chester, OH, USA). A COATEST Heparin kit (Chromogenix) was used to measure the units of extracted heparin according to the manufacturer's instructions. Standard solutions were prepared by dissolving the standard heparin in DW at concentrations of $0.2 \mathrm{IU} / \mathrm{mL}$ (1 $\mu \mathrm{g} / 9.6 \mathrm{~mL}$ ), and the extracted heparin was analyzed at a concentration of $0.2 \mu \mathrm{g} / \mathrm{mL}$ (Fig. 4).

\section{Measurement of angiotensin l-converting enzyme (ACE) inhibitory activity}

ACE inhibitory activity was measured according to the method of Cushman and Cheung [26], with slight modifications. ACE solution was prepared by adding rabbit lung acetone powder (Sigma-Aldrich) at a concentration of $50 \mathrm{mg} / \mathrm{mL}$ to $0.01 \mathrm{M}$ potassium phosphate buffer ( $\mathrm{pH} 7.0)$ containing $0.5 \mathrm{M}$ sodium chloride, stirring for $18 \mathrm{~h}$, and centrifuging at 10,280×g for $60 \mathrm{~min}$ to obtain the supernatant. Hippuryl-His-Leu (HHL) solution was prepared by mixing $0.05 \mathrm{M}$ sodium tetraborate and $0.05 \mathrm{M}$ boric acid to a $\mathrm{pH}$ of 8.3 and then adding hippuryl-1-histidyl-1-leucine to this $0.05 \mathrm{M}$ sodium borate buffer ( $\mathrm{pH}$ 8.3). Then, $50 \mu \mathrm{L}$ of $\mathrm{HHL}$ was added to standard heparin or $50 \mu \mathrm{L}$ of extracted heparin, and the mixture was reacted at $37^{\circ} \mathrm{C}$ for $10 \mathrm{~min}$. $\mathrm{ACE}(50 \mu \mathrm{L})$ was added to this and reacted at $37^{\circ} \mathrm{C}$ for $30-60 \mathrm{~min}$. After that, $250 \mu \mathrm{L}$ of $1 \mathrm{~N} \mathrm{HCl}$ and $250 \mu \mathrm{L}$ of ethyl acetate were added and vortexed for $1 \mathrm{~min}$. After completion of the reaction, the mixture was centrifuged at 1,977 $\mathrm{xg}$ for $10 \mathrm{~min}$. The $200 \mu \mathrm{L}$ of hippuric acid in the supernatant was added to a new tube and completely dried in a drying oven (WOF-50, Daihan scientific, Wonju, Korea). The dried sample was dissolved in $1 \mathrm{~mL}$ of water just before measurement and placed in a cuvette. The dried sample was measured using a UV/VIS spectrophotometer (Cary 300 UV VIS, Agilent Technologies, Santa Clara, CA, USA) at a wavelength of $228 \mathrm{~nm}$. To measure the antihypertensive activity of the sample, the control reaction was carried out by adding DW instead of the sample. After adding the substrate to the blank, the reacted value was measured by adding $0.05 \mathrm{M}$ sodium borate instead of ACE. The absorbance value was substituted into the following equation to evaluate the antihypertensive activity:

Table 1. High performance liquid chromatography (HPLC) conditions for heparin analysis

\begin{tabular}{ll}
\hline \multicolumn{1}{c}{ Parameter } & \multicolumn{1}{c}{ Condition } \\
\hline HPLC model & HP Agilent 1100, Hewlett Packard, Palo Alto, CA, USA \\
Column & Fortis $\mathrm{H}_{2} \mathrm{O} \mathrm{C}_{18}(150 \times 4.6 \mathrm{~mm}$ id, $5 \mu \mathrm{m})$ \\
Mobile phase & Distilled water $(\mathrm{DW})$ \\
Injection volume & $20 \mu \mathrm{L}$ \\
Flow rate & $1 \mathrm{~mL} / \mathrm{min}$ \\
Column temperature & $30^{\circ} \mathrm{C}$ \\
Detector & UV $210 \mathrm{~nm}$ \\
\hline
\end{tabular}




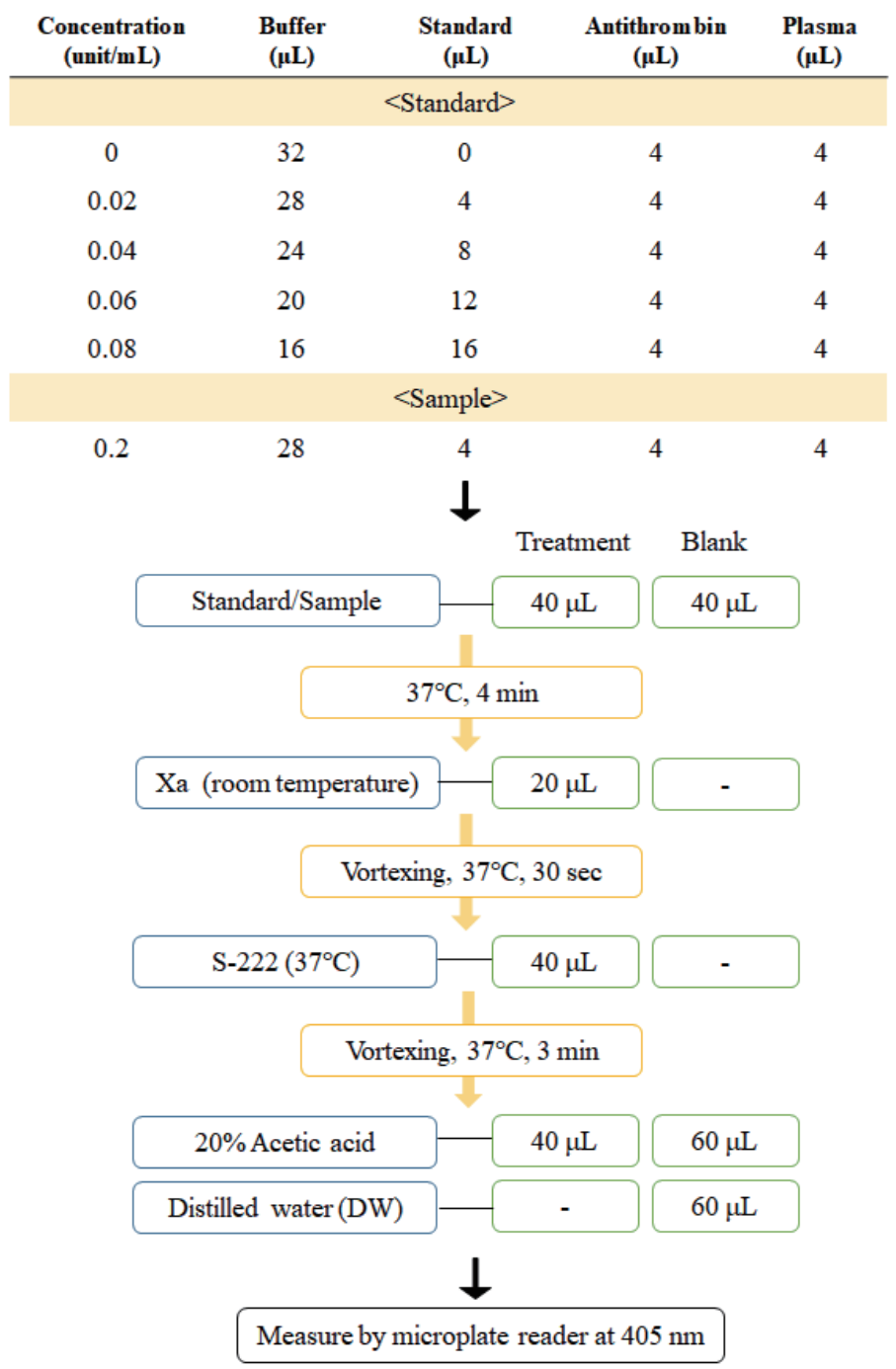

Fig. 4 . Assay of standard/sample heparin

$$
\mathrm{ACE} \text { inhibitory }=\frac{\mathrm{C}-\mathrm{S}}{\mathrm{C}-\mathrm{B}} \times 100
$$

where $\mathrm{C}$ is the absorbance value of the control, $\mathrm{B}$ is the absorbance value of the blank, and $\mathrm{S}$ is the absorbance value of standard heparin or extracted heparin.

\section{Measurement of antimicrobial activity}

In order to measure the antimicrobial activity of heparin, four kinds of bacteria, Listeria monocytogenes ATCC 7644, Pseudomonas aeruginosa KCTC $1750^{\mathrm{T}}$ (= ATCC 10145), Escherichia coli ATCC 25922, and Staphylococcus aureus ATCC 33591 were used. The viable count of microorganisms was determined by counting the number of colonies formed after incubation at $37^{\circ} \mathrm{C}$ for $24 \mathrm{~h}$. Brain heart infusion broth and agar (BHIB/BHIA, BD Difco ${ }^{\mathrm{TM}}$, Franklin Lakes, NJ, USA) was used as culture media for culturing the bacteria. The bacteria cultured in $\mathrm{BHIB}$ at $37^{\circ} \mathrm{C}$ for $12 \mathrm{~h}$ was inoculated BHIA at $37^{\circ} \mathrm{C}$ for $24 \mathrm{~h}$ to measure the number of viable microorganisms. Based on the number of viable microorganisms, the bacteria cultured for $12 \mathrm{~h}$ were diluted to $1 \times 10^{7} \mathrm{CFU} / \mathrm{mL}$. 
Then $0.625-10 \mathrm{mg} / \mathrm{mL}$ standard heparin was diluted 9:1 in the medium (medium: heparin). The cultured bacteria were divided into 96 cell culture plates (SPL, Pocheon, Korea) for 0, 2, 4, 6, 8, 12, and $24 \mathrm{~h}$ and analyzed using a microplate reader (ELISA [enzyme-linked immunosorbent assay device], Spectramax 190, Molecular Devices, San Jose, CA, USA), and the relative antibacterial activity was calculated. For the extracted heparin, concentrations of $5-20 \mathrm{mg} / \mathrm{mL}$ were prepared and the turbidity of the culture was measured.

\section{Statistical analysis}

Statistical analysis of the experiment was conducted by one-way ANOVA using the SPSS 22.0 program (IBM, Armonk, NY, USA). Statistical significance was assessed using the multi-range test of Student-Newman-Keuls' and significance level of all data was evaluated based on $p<0.05$.

\section{RESULTS AND DISCUSSION}

\section{Pre-processing of pig by-products}

The amount of defatted pig by-product powder was significantly different among the organs. The liver, lungs, and heart had an average of about $19.5 \%$ of defatted-dried organ, and the stomach, small intestine, and large intestine, which are relatively hydrated, had $10.7 \%$ of defatted-dried organs (Fig. 5). The amount of defatted pig by-product powder was $420 \mathrm{~g}$ in liver, $162 \mathrm{~g}$ in lung, $83 \mathrm{~g}$ in heart, $105 \mathrm{~g}$ in stomach, $161 \mathrm{~g}$ in small intestine, and $40 \mathrm{~g}$ in the large intestine (Fig. 5) from 500 $\mathrm{g}$ of the pig by-product. This accounts for about $16 \%$ of the total $6 \mathrm{~kg}$ of pig by-product that are left after slaughter. The defatted-dried by-products are advantageous in delaying the decay of the by-products, thereby increasing the shelf life of the by-products, and reducing the cost of storage by reducing the volume of the sample.

\section{Heparin extraction in pig by-products}

The extraction rate of heparin from each by-product was based on the weight of pig by-products before manufacturing the defatted pig by-product powder. Heparin was extracted at the highest

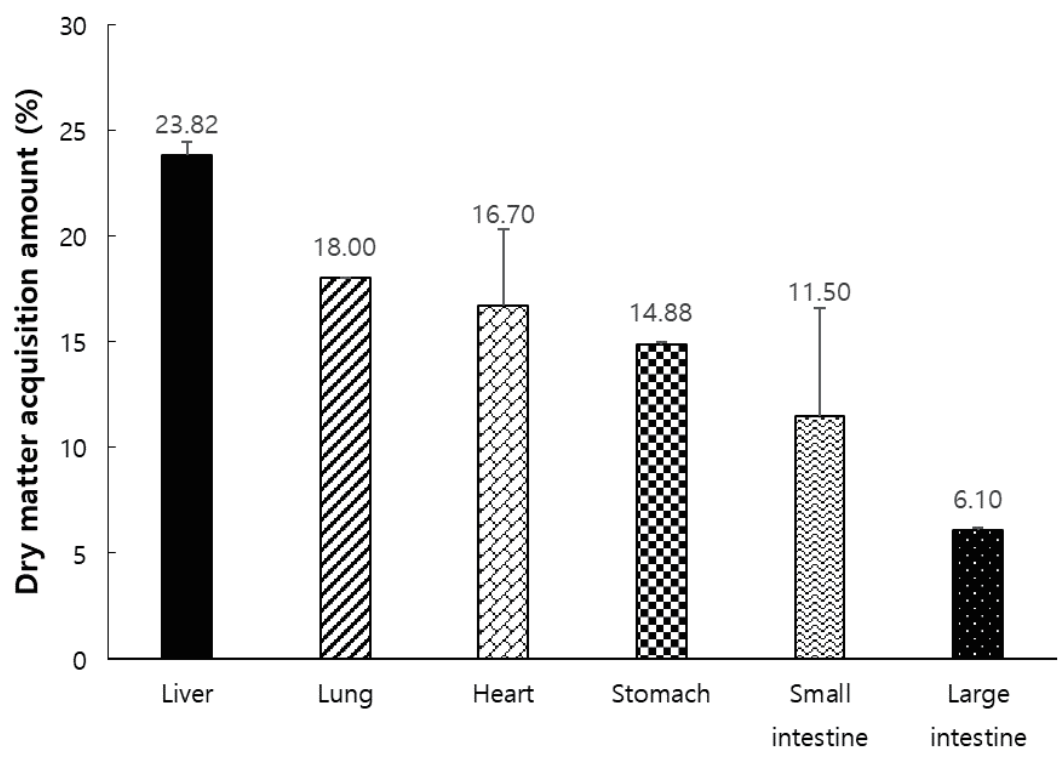

Fig. 5. Defatted dry matter acquisition amount of pig by-products. Data are given as mean values $\pm S D(n=3)$. 
rate in the liver and heart and was relatively low in the lung (Fig. 6, Table 2). These results indicate that the amount of heparin extracted from pig livers was similar to or greater than the results from a previous study [20]. The calculated amount of heparin extracted from total pig by-products was about $1,718 \mathrm{mg}$ extracted by trypsin, about $1,697 \mathrm{mg}$ extracted by papain, and about $1,905 \mathrm{mg}$ extracted by alkaline-AK enzyme (Fig. 6, Table 2). In the conventional heparin extraction methods, proteolytic enzymes such as trypsin are used to remove proteins $[19,20,22]$. However, this study attempted to extract heparin using alkaline-AK, an industrial enzyme which is inexpensive, and a high titer enzyme, such as papain. Alkaline-AK is a proteolytic enzyme obtained by fermenting soybean meal by-products, which is about 1.3 million times cheaper than trypsin and 2,000 times cheaper than papain. The extraction of heparin after the acquisition of crude fat using Folch I reagent seems to reduce the final heparin extraction amount, but it generates additional benefits from the high value substances obtained in the crude fat.

\section{Quantification of heparin by high-performance liquid chromatography (HPLC)}

Glycosaminoglycan-based materials such as heparin can be identified using various chromatographic methods such as HPLC [25,27-29], UPLC [30], and liquid chromatography-mass spectrometry (LC/MS) [31,32]. Heparin is a strongly negatively charged substance [25,27-29]. When using reverse phase chromatography, heparin is first separated from the column by binding to a po-

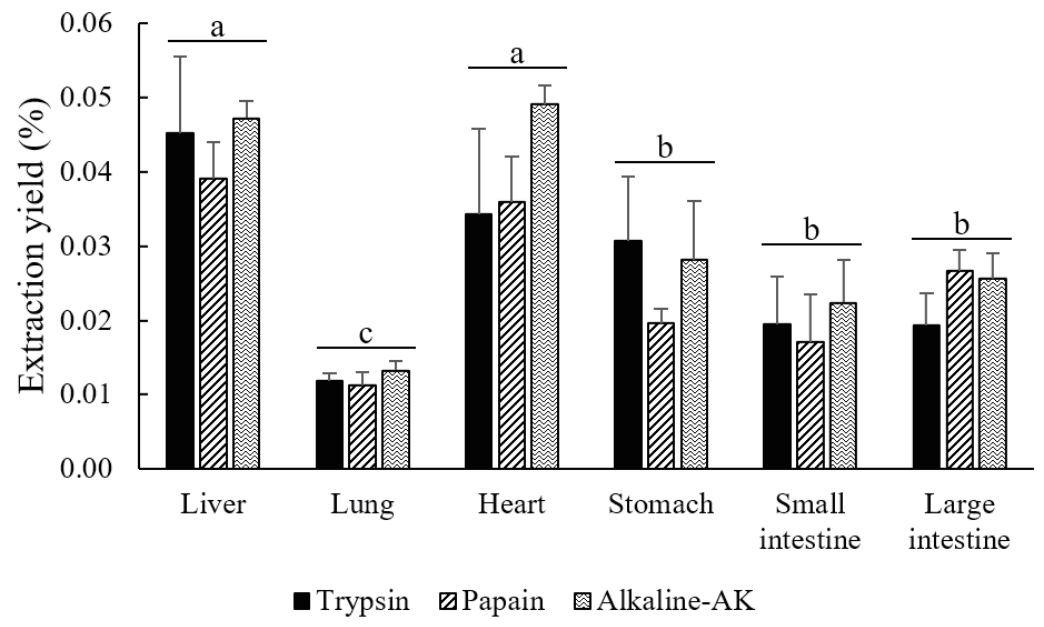

Fig. 6. Extracted heparin yield from pig by-products. Data are given as mean values $\pm S D(n=3) .{ }^{2-c} p<0.05$ depends on organ.

Table 2. Comparison of yield of heparin extracted from pig organs using three different enzymes

\begin{tabular}{lccc}
\hline \multirow{2}{*}{ Organ } & \multicolumn{3}{c}{ Extracted heparin $(\mathrm{mg})$} \\
\cline { 2 - 4 } & Trypsin & Papain & Alkaline-AK \\
\hline Liver & $453 \pm 102^{\mathrm{a}}$ & $391 \pm 49^{\mathrm{a}}$ & $473 \pm 22^{\mathrm{a}}$ \\
Lung & $118 \pm 11^{\mathrm{c}}$ & $112 \pm 18^{\mathrm{c}}$ & $132 \pm 13^{\mathrm{c}}$ \\
Heart & $344 \pm 115^{\mathrm{a}}$ & $359 \pm 62^{\mathrm{a}}$ & $491 \pm 26^{\mathrm{a}}$ \\
Stomach & $308 \pm 86^{\mathrm{b}}$ & $196 \pm 19^{\mathrm{b}}$ & $281 \pm 79^{\mathrm{b}}$ \\
Small intestine & $195 \pm 64^{\mathrm{b}}$ & $171 \pm 64^{\mathrm{b}}$ & $224 \pm 58^{\mathrm{b}}$ \\
Large intestine & $194 \pm 44^{\mathrm{b}}$ & $266 \pm 28^{\mathrm{b}}$ & $256 \pm 34^{\mathrm{b}}$
\end{tabular}

Extracted heparin yield per original pig by-products $1 \mathrm{~kg}$. Data are given as mean values $\pm S D(n=3)$.

${ }^{a-c} p<0.05$ depends on organ. 
lar mobile phase. In this study, the small intestines contained the largest amount of heparin in $1 \mathrm{~g}$ of extracted heparin, and a relatively small amount of heparin was identified in the heart and stomach. This indicates that a high purity heparin is extracted in the small intestine and a low purity heparin is extracted in the heart and stomach. The statistical analysis confirmed that there was a significant difference in the amount of pure heparin by enzyme in each by-product. As a result, high purity heparin can be obtained using trypsin is higher than the others in the liver, lungs, heart, and small intestine. In the large intestine, papain is higher than the others. In the stomach, heparin of similar purity was obtained by the three enzymes. The average amount of heparin extracted by enzymes was confirmed in the order of trypsin is greater than or equal to papain, alkaline-AK (Figs. 7A and 7B).

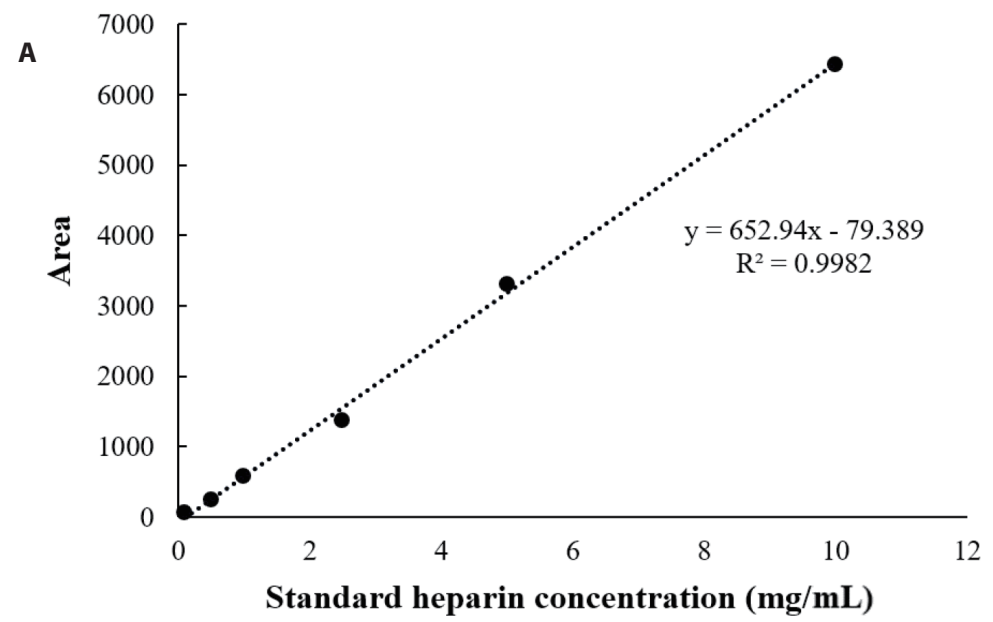

B

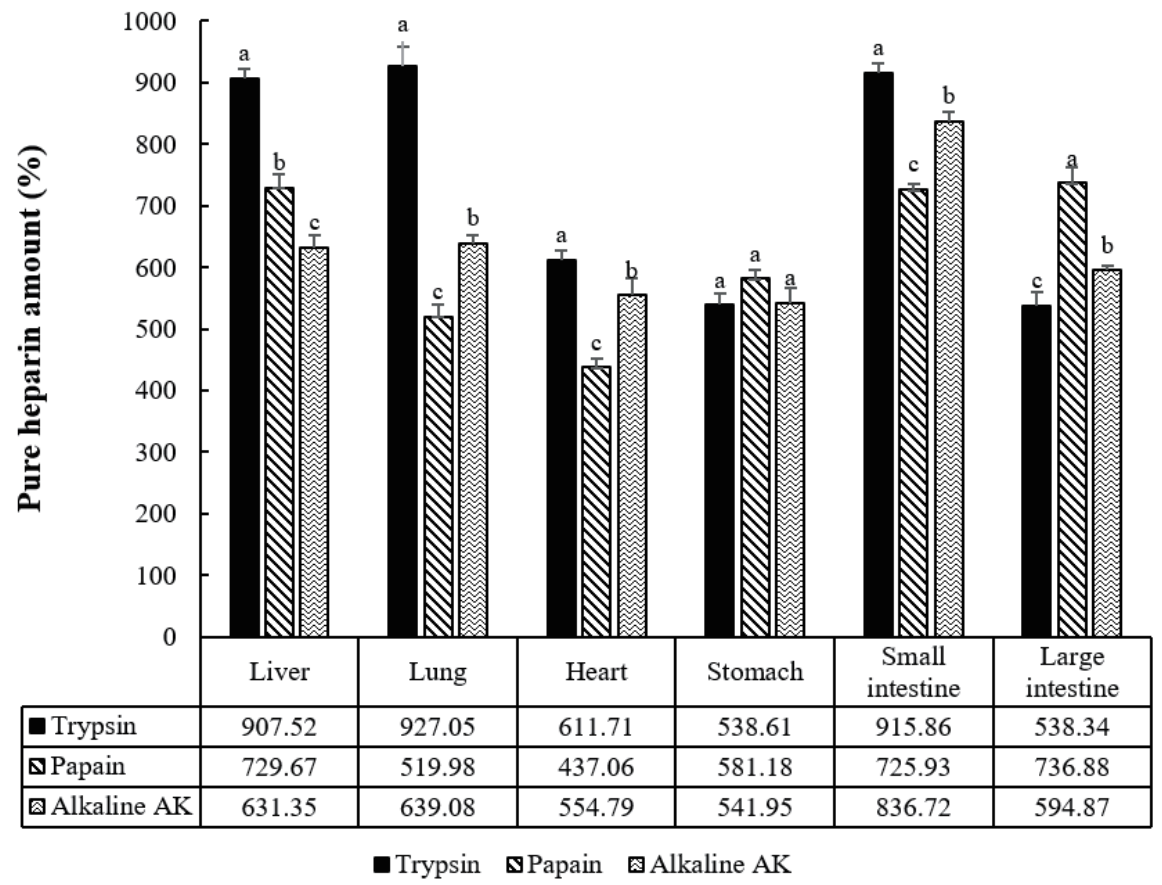

Fig. 7. HPLC analysis of extracted heparin (A) standard calibration curve of standard heparin amount, (B) determination of pure heparin amount per extracted gram of heparin using HPLC. Data are given as mean values $\pm S D(n=3) .{ }^{a-c} p<0.05$ depends on enzyme in same organ. 


\section{COATEST heparin assay}

COATEST heparin assay quantifies the units of heparin. Heparin is analyzed in the form of a complex with anti-thrombin present in the sample. The units/mg of extracted heparin were similar in almost all pig by-products, but heparin extracted from the stomach was found to contain the highest amount of heparin at an average of 2,670 units/mg. The liver showed significant differences in units extracted by enzymes, in the order of alkaline-AK and papain greater than trypsin. In the case of the other by-products, there was a difference in the amount of extracted enzymes but there was no significant difference because the standard deviation was too large (Figs. 8A and 8B). However, the average amount of enzyme in the total by-products was in the order of papain and alkaline-AK greater than trypsin. It is assumed that the difference in the amounts of heparin in the same sample may be due to the proteolytic action of trypsin (serine peptidase) and papain (cysteine peptidase) [33].

A

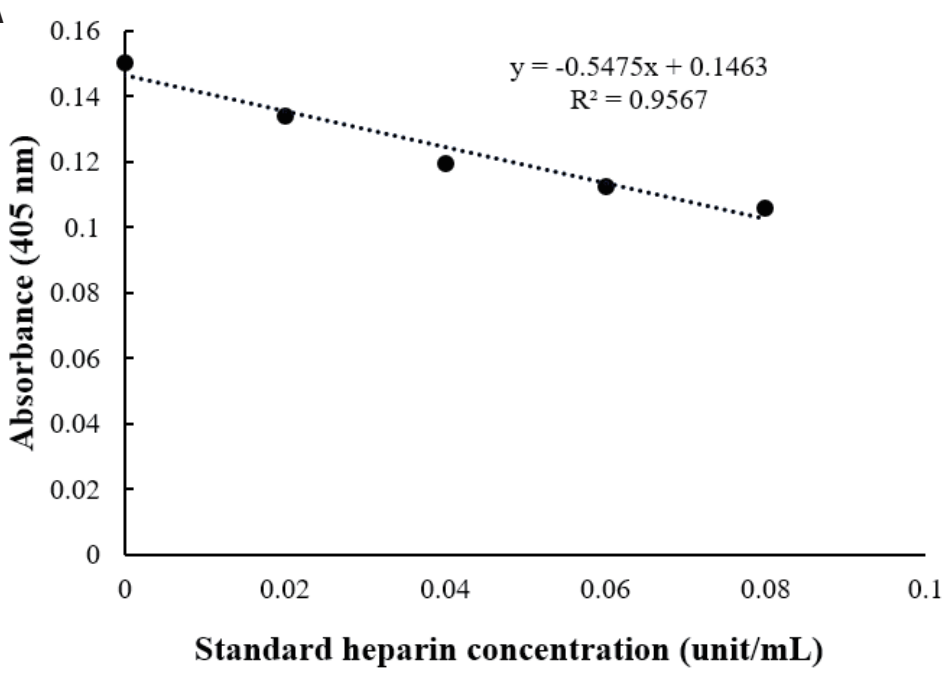

B

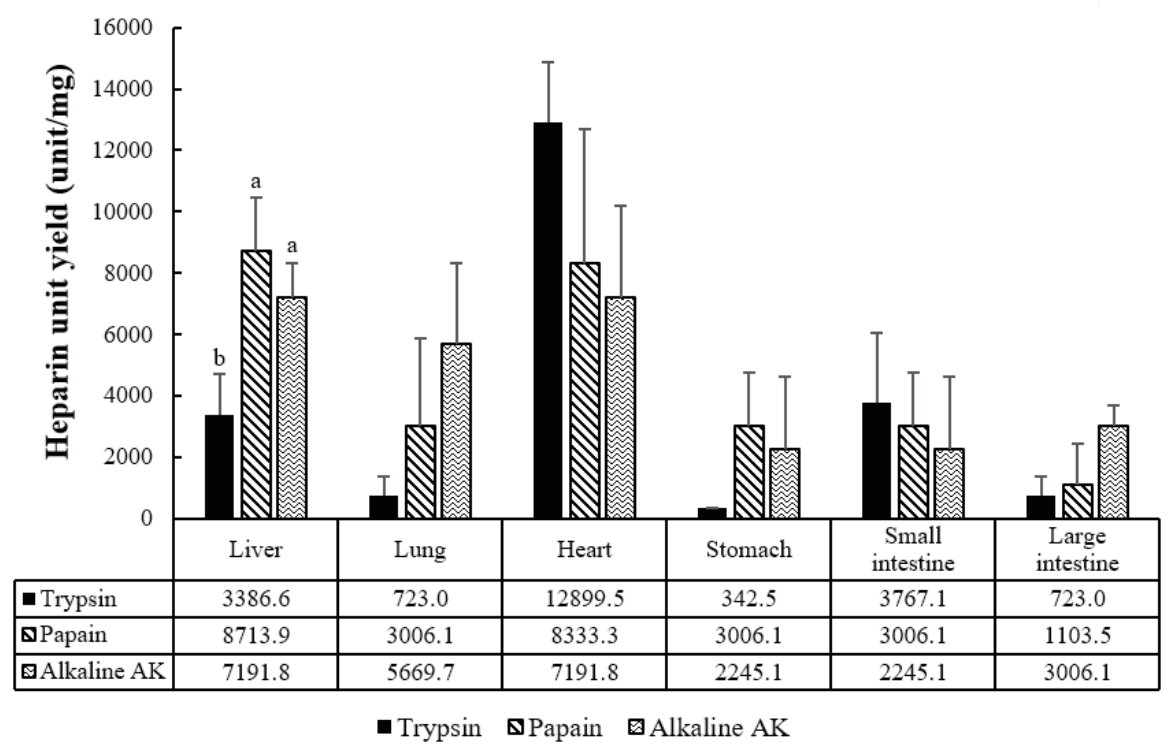

Fig. 8. COATEST heparin assay of extracted heparin (A) standard calibration of standard heparin unit, (B) determination of heparin unit amount per milligram of extracted heparin using a COATEST heparin assay. Data are given as mean values $\pm \operatorname{SD}(n=4) .{ }^{a-c} p<0.05$ depends on enzyme in same organ. 


\section{Measurement of angiotensin I-converting enzyme inhibitory activity}

Studies on the antihypertensive activity of heparin have been conducted since the 20th century. Heparin inhibits the production of angiotensin by renin [12], and suppresses aldosterone secretion $[11,13]$, and therefore is antihypertensive. Based on the previous studies, an experiment was conducted to confirm whether heparin extracted through an ACE inhibitory activity assay has antihypertensive activity that inhibits the production of angiotensin II (Fig. 9). Heparin extracted with papain had the highest antihypertensive activity (72.5\%) and extracted heparin showed higher antihypertensive activity in alkaline-AK and trypsin (Fig. 10). Based on the results of the COATEST heparin assay, it can be inferred that the treatment containing the highest amount of heparin

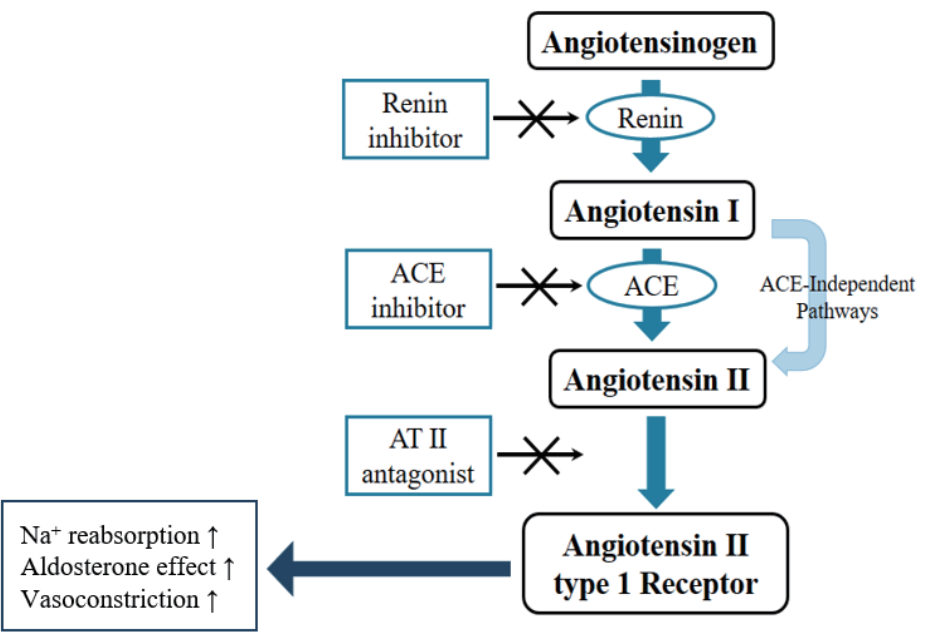

Fig. 9. Mechanism of the renin angiotensin system. ACE, anti-angiotensin I-converting enzyme.

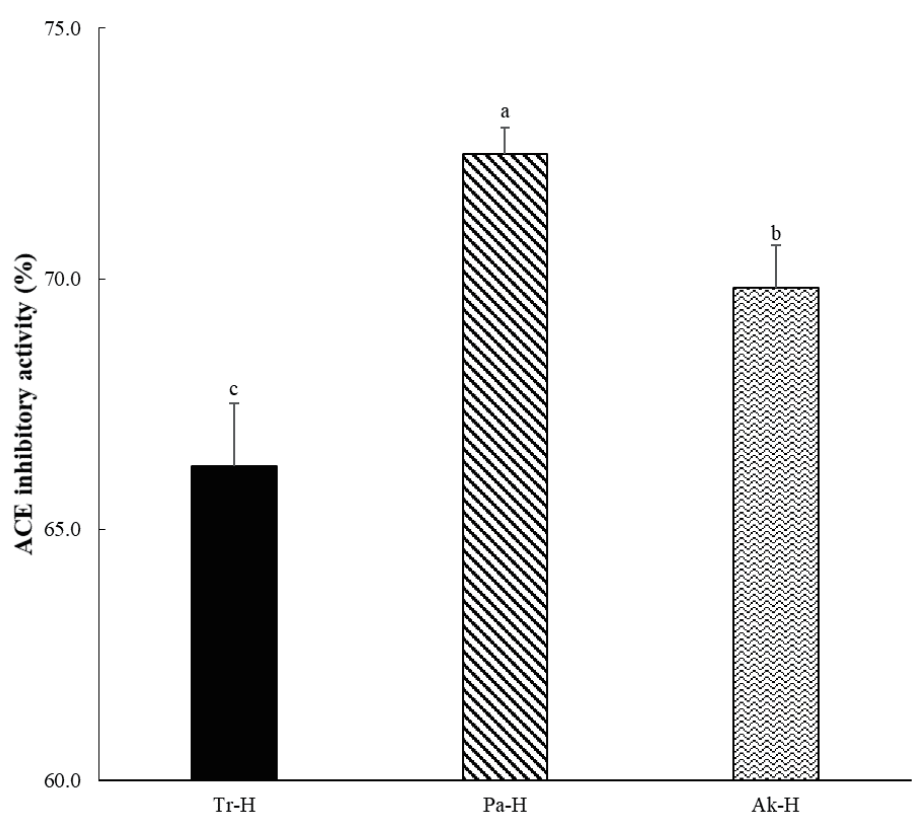

Fig. 10. ACE inhibitory activity of extracted heparin using different enzymes $(2 \mathrm{mg} / \mathrm{mL})$. Data are given as mean values $\pm S D(n=4) .{ }^{a-c} p<0.05$ depends on enzyme. ACE, anti-angiotensin l-converting enzyme. 
showed higher ACE inhibitory activity.

\section{Measurement of antimicrobial activity}

In the case of $S$. aureus, $2 \mathrm{mg} / \mathrm{mL}$ heparin was added to a medium containing an initial bacterial count of $1.21 \times 10^{3} \mathrm{CFU} / \mathrm{mL}$. Heparin extracted by papain and alkaline-AK were shown to have an antimicrobial activity at low concentration (Fig. 11). However, in the case of L. monocytogens, E. coli, and P. aeruginosa, all the treatments in the samples cultured for $12 \mathrm{~h}$ did not grow compared to the control, but an antibacterial effect of heparin was not found (Fig. 11). As a result, the antimicrobial activity of the extracted heparin could not be confirmed and the regularity of the antimicrobial activity treatment by concentration could not be confirmed. These results suggest that there is no antibacterial activity of heparin against $P$. aeruginosa, or that the antimicrobial activity was not exhibited by using an excessive concentration of bacteria (Fig. 11).

Heparin can be extracted from pig by-products, and is used in the medical fields for anticoagu-
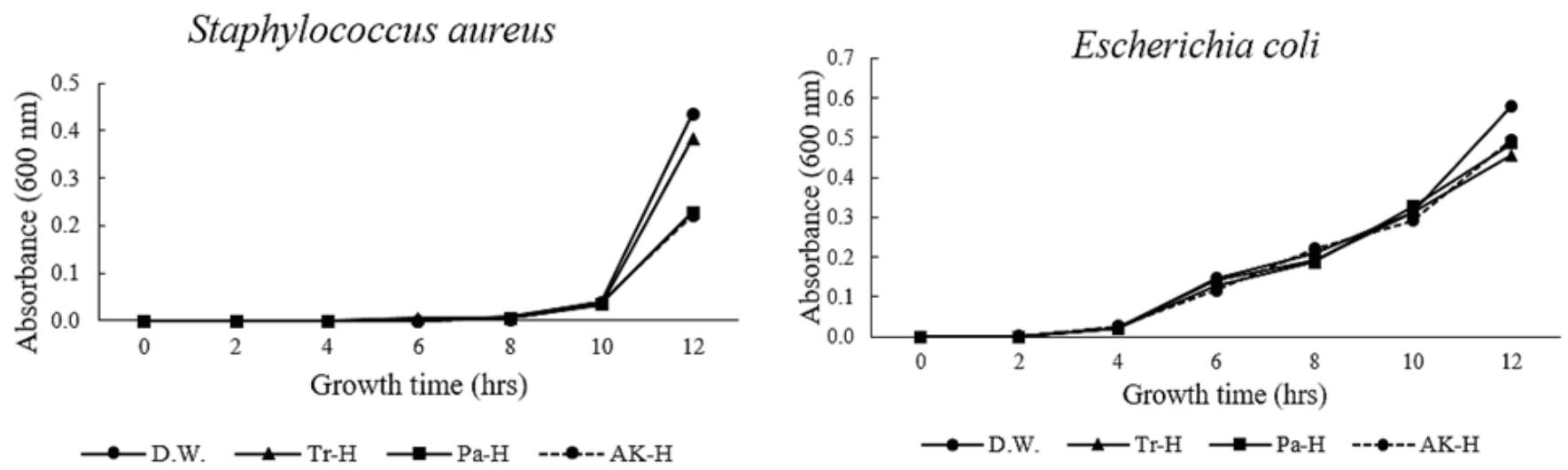

\section{Listeria monocytogenes}
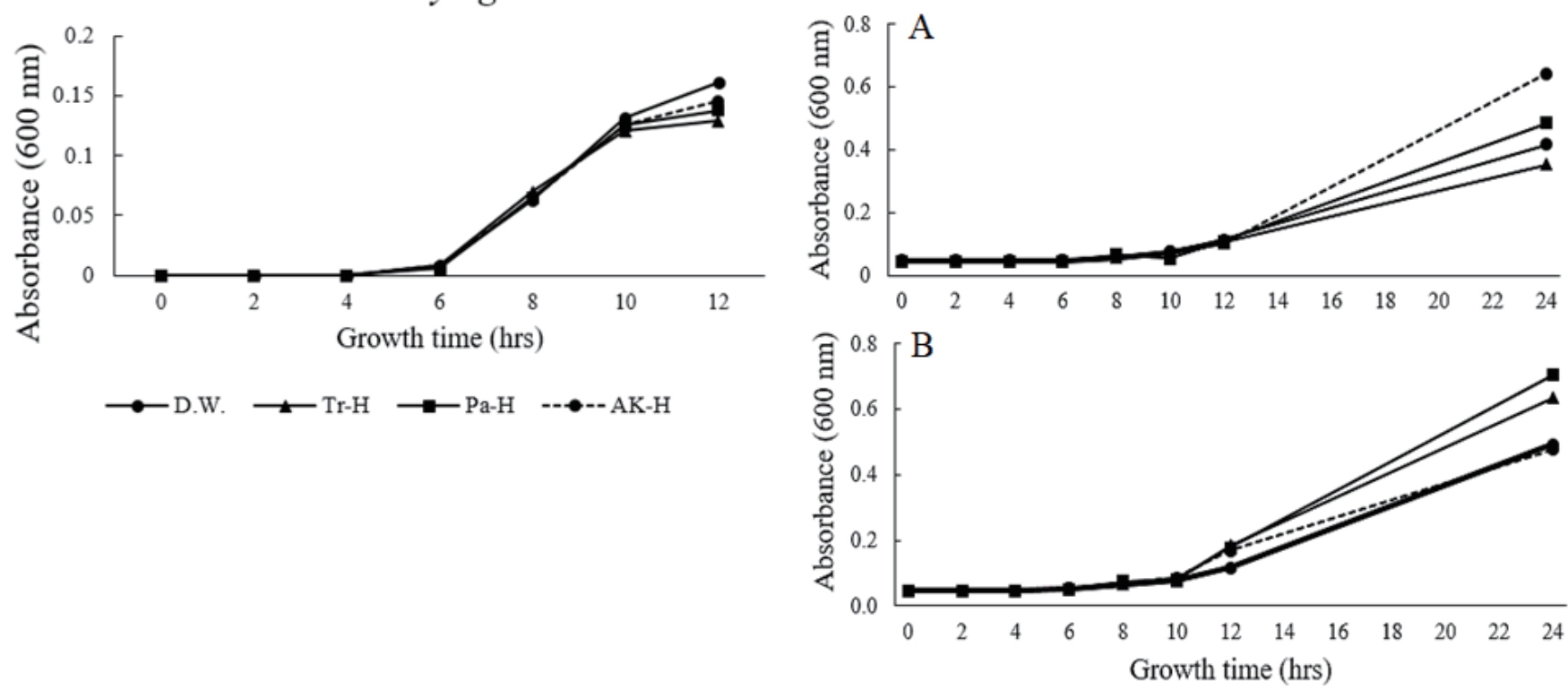

Fig. 11. Antimicrobial activity of extracted heparin using different enzymes in Staphylococcus aureus, Listeria monocytogenes, Escherichia coli, Pseudomonas aeruginosa ( $2 \mathrm{mg} / \mathrm{mL}$ ). 
lant purposes. Heparin, which has been commercialized in the past, was limited to extractions from the pig small intestine, and heparin in other pig by-products was not utilized. Various studies have been conducted to reduce the disposal cost of the discarded pig by-products and further industrialize them [1]. The current study carried out experiments on the extraction, quantification, and validation of heparin. In this study, heparin was extracted from not only the small intestine (as is usually done), but also from six other major pig by-products. Using various types of proteolytic enzymes (papain and alkaline-AK), it was confirmed that heparin extraction could be similar to or greater than that of conventional enzyme extractions (trypsin), but using inexpensive and high titer enzymes. The above findings confirm that heparin can be extracted by a faster and simpler extraction method than the existing extraction method, and can verify the amount of heparin contained in the pig by-product. Heparin was purified immediately after extraction and subjected to quantitative analysis to confirm the amount. As a result of measuring the purity of extracted heparin by HPLC, extracted heparin from each enzyme showed similar purity. Among them, heparin extracted from the liver and small intestine were shown to have the highest purity. The COATEST heparin assay, which measures the units of heparin, indicated the highest extractions of heparin from the liver and heart. Based on the total amount of liver, it was confirmed that $\mathrm{Pa}-\mathrm{H}$ (heparin extracted using papain) and $\mathrm{AK}-\mathrm{H}$ (heparin extracted using alkaline- $\mathrm{AK}$ ) contained more units than $\mathrm{Tr}-\mathrm{H}$ (heparin extracted using trypsin).

$\mathrm{ACE}$ inhibitory activity and antimicrobial activity were measured to verify the efficacy of the extracted heparin. In the ACE inhibitory activity experiment, the activities were confirmed in the order of $\mathrm{Pa}-\mathrm{H}, \mathrm{Ak}-\mathrm{H}$, and $\mathrm{Tr}-\mathrm{H}$. This was similar to the units of extracted heparin analyzed by the COATEST heparin assay. Based on these results, it could be assumed that high heparin content confers ACE inhibitory activity. The antimicrobial activity of heparin (according to heparin units) was confirmed in $S$. aureus. No distinct antimicrobial activity was found against $L$. monocytogenes, $E$. coli, and $P$. aeruginos, which may require further investigation.

\section{The results of this study are summarized as follows:}

1. The use of crude fat and protein generated during heparin extraction shortens the extraction time, and enzyme differentiation improved the efficiency of heparin extraction from pig by-products.

2. Data were presented to indicate the amount of heparin per pig by-product. The average amount of extracted heparin per kilogram of pig by-product was $439 \mathrm{mg}$ from the liver, $127 \mathrm{mg}$ from the lung, $398 \mathrm{mg}$ from the heart, $261 \mathrm{mg}$ from the stomach, $197 \mathrm{mg}$ from the small intestine, and $239 \mathrm{mg}$ from the large intestine.

3. Various enzymes were used to extract heparin, and the amount of extracted heparin was similar. Based on the major pig by-products (from one pig), trypsin, papain, and alkaline-AK enzymes extracted 1,718 mg, 1,697 mg, and 1,905 mg heparin, respectively.

4. Heparin showed antihypertensive activity and antimicrobial activity against $S$. aureus, and confirmed the possibility as a material to prevent or suppress disease.

For industrialization and mass production of heparin, it is important to establish a low-cost extraction process that can secure national competitiveness. Therefore, in this study, a method to reduce the production cost of heparin and generate additional profits was developed by simplifying the process and using inexpensive alkaline-AK (1.3 million times cheaper than trypsin, and 2,000 times cheaper than papain). Alkaline-AK enzyme extraction can obtain similar amounts of heparin compared to other enzymes and reduce the cost of the extraction process. Extracting heparin after crude fat is removed can reduce the use of enzymes and generate additional profits. Heparin's ACE 
inhibitory activity and antimicrobial activity, which have not been fully studied, were confirmed, confirming the potential of heparin as a drug. Therefore, further investigation should be directed here in the future.

\section{REFERENCES}

1. Choi JP. Animal byproduct(blood) current status \& usage. Korean J Food Sci Anim Resour. 2013;2:2-7.

2. Jeon KH. Current production and utilization of animal by-products. Korean J Food Sci Anim Resour. 2013;2:8-16.

3. Yoon SY, Lee DY, Kim OY, Lee SY, Hur SJ. Development of commercially viable method of conjugated linoleic acid synthesis using linoleic acid fraction obtained from pork by-products. Korean J Food Sci Anim Resour. 2018;38:693. https://doi.org/10.5851/kosfa.2018.e6

4. Lee SY, Yoon SY, Lee DY, Kim OY, Kim HS, Jung EY, et al. Development of batch processing to obtain bioactive materials from pork byproducts. Anim Prod Sci. 2020;60:316-22. https:// doi.org/10.1071/AN18600

5. Tyagi AK, Kumar S, Choudhury PK, Tyagi B, Tyagi N. Conjugated linoleic acid producing potential of lactobacilli isolated from goat (AXB) rumen fluid samples. Asian-Australas J Anim Sci. 2020;33:1233. https://doi.org/10.5713/ajas.19.0080

6. Lee MS, Kong J. Heparin: physiology, pharmacology, and clinical application. Rev Cardiovasc Med. 2015;16:189-99. https://doi.org/10.3909/ricm0778

7. Howell $\mathrm{WH}$, Holt E. Two new factors in blood coagulation: heparin and pro-antithrombin. Am J Physiol. 1918;47:328-41. https://doi.org/10.1152/ajplegacy.1918.47.3.328

8. Petitou M, Casu B, Lindahl U. 1976-1983, a critical period in the history of heparin: the discovery of the antithrombin binding site. Biochimie. 2003;85:83-9. https://doi.org/10.1016/ S0300-9084(03)00078-6

9. Lever R, Page CP. Novel drug development opportunities for heparin. Nat Rev Drug Discovery. 2002;1:140. https://doi.org/10.1038/nrd724

10. Sun W, Han J, Li Q, Jiao K. Spectrophotometric and voltammetric studies on the interaction of heparin with crystal violet and its analytical application. S Afr J Chem. 2007;60:42-6.

11. Abbott EC, Gornall AG, Sutherland DJA, Stiefel M, Laidlaw JC. The influence of a heparin-like compound on hypertension, electrolytes and aldosterone in man. Can Med Assoc J. 1966;94:1155-64.

12. Sealey JE, Gerten JN, Ledingham JGG, Laragh JH. Inhibition of renin by heparin. J Clin Endocrinol Metab. 1967;27:699-705. https://doi.org/10.1210/jcem-27-5-699

13. Susie D, Mandal AK, Jovovic D, Stojanov M, Djordjevic-Denic G, Kentera D. Antihypertensive action of heparin: role of the renin-angiotensin aldosterone system and prostaglandins. J Clin Pharmacol. 1993;33:342-7.

14. Droste JC, Jeraj HA, MacDonald A, Farrington K. Stability and in vitro efficacy of antibioticheparin lock solutions potentially useful for treatment of central venous catheter-related sepsis. J Antimicrob Chemother. 2003;51:849-55. https://doi.org/10.1093/jac/dkg179

15. Miceli MH, Bernardo SM, Ku TN, Walraven C, Lee SA. In vitro analyses of the effects of heparin and parabens on Candida albicans biofilms and planktonic cells. Antimicrob Agents Chemother. 2012;56:148-53. https://doi.org/10.1128/AAC.05061-11

16. Hanno PM, Fritz R, Wein AJ, Mulholland SG. Heparin as antibacterial agent in rabbit bladder. Urology. 1978;12:411-5. https://doi.org/10.1016/0090-4295(78)90291-1

17. Rosett W, Hodges GR. Antimicrobial activity of heparin. J Clin Microbiol. 1980;11:30-4. 
https://doi.org/10.1128/JCM.11.1.30-34.1980

18. Arciola CR, Bustanji Y, Conti M, Campoccia D, Baldassarri L, Samorì B, et al. Staphylococcus epidermidis-fibronectin binding and its inhibition by heparin. Biomaterials. 2003;24:3013-9. https://doi.org/10.1016/S0142-9612(03)00133-9

19. Charles AF, Scott DA. Studies on heparin I. The preparation of heparin. Int J Biol Chem. 1933;102:425-9.

20. Charles AF, Scott DA. Studies on heparin II. Heparin in various tissues. Int J Biol Chem. 1933;102:431-5.

21. Charles AF, Scott DA. Studies on heparin III. The purification of heparin. Int J Biol Chem. 1933;102:437-48.

22. Freeman L, Posthuma R, Gordon L, Marx W. Determination of tissue heparin. Arch Biochem Biophys. 1957;70:169-77. https://doi.org/10.1016/0003-9861(57)90090-5

23. Volpi N. Disaccharide analysis and molecular mass determination to microgram level of single sulfated glycosaminoglycan species in mixtures following agarose-gel electrophoresis. Anal Biochem. 1999;273:229-39. https://doi.org/10.1006/abio.1999.4218

24. Sarwar MI, Hussain MS, Rauf A. Heparin can be isolated and purified from bovine intestine by different techniques. Int J Pharm Sci Invent. 2013;2:21-5.

25. Arumugam M, Shanmugam A. Extraction of heparin and heparin-like substance from marine mesogastropod mollusc Turritella attenuata (Lamarck, 1779). Indian J Exp Biol. 2004;42:52932.

26. Cushman DW, Cheung HS. Spectrophotometric assay and properties of the angiotensin-converting enzyme of rabbit lung. Biochem Pharmacol. 1971;20:1637-48. https://doi. org/10.1016/0006-2952(71)90292-9

27. Delaney SR, Leger M, Conrad HE. Quantitation of the sulfated disaccharides of heparin by high performance liquid chromatography. Anal Biochem. 1980;106:253-61. https://doi. org/10.1016/0003-2697(80)90145-1

28. Trehy ML, Reepmeyer JC, Kolinski RE, Westenberger BJ, Buhse LF. Analysis of heparin sodium by SAX/HPLC for contaminants and impurities. J Pharm Biomed Anal. 2009;49:670-3. https://doi.org/10.1016/j.jpba.2008.12.013

29. Imanari T, Toida T, Koshiishi I, Toyoda H. High-performance liquid chromatographic analysis of glycosaminoglycan-derived oligosaccharides. J Chromatogr A.1996;720:275-93. https://doi. org/10.1016/0021-9673(95)00338-X

30. Yang B, Chang Y, Weyers AM, Sterner E, Linhardt RJ. Disaccharide analysis of glycosaminoglycan mixtures by ultra-high-performance liquid chromatography-mass spectrometry.J Chromatogr A. 2012;1225:91-8. https://doi.org/10.1016/j.chroma.2011.12.063

31. Auray-Blais C, Bhérer P, Gagnon R, Young SP, Zhang HH, An Y, et al. Efficient analysis of urinary glycosaminoglycans by LC-MS/MS in mucopolysaccharidoses type I, II and VI. Mol Genet Metab. 2011;102:49-56. https://doi.org/10.1016/j.ymgme.2010.09.003

32. Auray-Blais C, Lavoie P, Zhang H, Gagnon R, Clarke JT, Maranda B, et al. An improved method for glycosaminoglycan analysis by LC-MS/MS of urine samples collected on filter paper. Clinica Chimica Acta. 2012;413:771-8. https://doi.org/10.1016/j.cca.2012.01.012

33. Rawlings ND, Barrett AJ. Evolutionary families of peptidases. Biochem J. 1993;290:205-18. https://doi.org/10.1042/bj2900205 